\title{
Synthesis and Characterization of Tolvaptan Impurities
}

\author{
Madhuresh Kumar Sethi, Vijendra Singh Rawat, Jayaprakash Thirunavukarasu, \\ Rajakrishna Yerramalla, and Anish Kumar
}

R and D, Mylan Laboratories Ltd., Plot No. 31, 32, 33 and 34 A ANRICH Industrial Estate, Bollaram, Jinnaram, Medak, Andhra Pradesh 502325, India

Correspondence should be addressed to Madhuresh Kumar Sethi; madhuresh.sethi@mylan.in

Received 12 May 2014; Accepted 26 June 2014; Published 10 July 2014

Academic Editor: Atsushi Ohtaka

Copyright (C) 2014 Madhuresh Kumar Sethi et al. This is an open access article distributed under the Creative Commons Attribution License, which permits unrestricted use, distribution, and reproduction in any medium, provided the original work is properly cited.

Twenty-six possible as well as observed impurities during the preparation of Tolvaptan have been identified, prepared, and characterized by HPLC (high performance liquid chromatography), NMR (nuclear magnetic resonance), and mass spectra. Control of these impurities, formed during various stages of Tolvaptan preparation, has been mentioned in this paper.

\section{Introduction}

Impurity profiling is a major step in the drug development process followed by drug making companies world over $[1,2]$. Impurities even if present in fairly small quantity could affect the overall safety and efficacy of the drug. Hence it is of tremendous importance to prepare an impurity profiling of the drug and to set their limits within the range set by $\mathrm{ICH}$ [3]. Drug related impurities could be classified into categories such as starting material, intermediate, degradation products, by-products derived from impurities in starting material and by-product stability, and shelf life derived from side reaction. There are several reports wherein impurities related to drug are first identified and then prepared and characterized by different methods such as MASS, NMR, and HPLC [4].

Tolvaptan (N-[ \pm-4 -[(7-chloro-2,3,4,5-tetrahydro-5-hydroxy-1H-1-benzazepin-1-yl) carbonyl]-3-methylphenyl]-2methyl-benzamide) is a drug used to treat hyponatremia associated with congestive heart failure, cirrhosis, and the syndrome of inappropriate antidiuretic hormone $[5,6]$. It is available under the brand name Samsca produced by Otsuka Pharmaceutical Co Ltd. Tolvaptan is metabolized by the CYP3A4 in the liver.

Various methods for synthesis of Tolvaptan have been reported in the literature [7-11]. During the preparation of Tolvaptan, impurities were detected in HPLC. Process used to prepare Tolvaptan involves condensing 7-chloro-1, 2, 3, 4-tetrahydro-benzo[b]azepin-5-one with 2-methyl, 4-nitro benzoyl chloride, followed by reduction using $\mathrm{SnCl}_{2} / \mathrm{HCl}$ catalyst resulting in amine which is then condensed with otoluoyl chloride followed by reduction with sodium borohydride to give Tolvaptan pharma (Scheme 1).

A comprehensive study was undertaken to synthesize and characterize these impurities by spectroscopic techniques. Present studies describe the synthesis and characterization of possible as well as observed impurities in the process for preparation of Tolvaptan. As per the guidelines recommended by ICH (the International Conference on Harmonisation of Technical Requirements for Registration of Pharmaceuticals for Human Use), the acceptable level for a known or unknown related compound (impurity) is less than 0.15 and $0.10 \%$, respectively, in a drug substance. In order to meet the stringent regulatory requirements, the impurities present in the drug substance must be identified and characterized. Present work deals with the identification, synthesis, and characterization of impurities/related substances of Tolvaptan.

\section{Experimental}

2.1. Materials and Methods. All the chemicals are commercially available and used without purification.The ${ }^{1} \mathrm{H}$ NMR was recorded in DMSO at $300 \mathrm{MHz}$ on a Bruker $300 \mathrm{MHz}$ Fourier transform NMR spectrometer. The chemical shifts were reported in $\delta \mathrm{ppm}$ relative to TMS. Mass spectrum was recorded on Agilent 1100 Series LC-MSD trap-SL system. 
<smiles>O=C1CCNc2ccc(Cl)cc21</smiles><smiles>Cc1cc([N+](=O)[O-])ccc1C(=O)Cl</smiles>

2-Methyl-4-nitro<smiles>Cc1ccccc1C(=O)Nc1ccc(C(=O)N2CCCC(=O)c3cc(Cl)ccc32)c(C)c1</smiles><smiles>Cc1ccccc1C(=O)Nc1ccc(C(=O)N2CCCC(=O)c3cc(Cl)ccc32)c(C)c1</smiles><smiles>Cc1cc([N+](=O)[O-])ccc1C(=O)N1CCCC(=O)c2cc(Cl)ccc21</smiles><smiles>Cc1ccccc1C(=O)Cl</smiles><smiles>Cc1cc(N)ccc1C(=O)N1CCCC(=O)c2cc(Cl)ccc21</smiles>

TLV-2

SCHEME 1: Synthetic route used for preparation of Tolvaptan.

\subsection{Synthetic Procedures}

2.2.1. Preparation of Tolvaptan Impurity A. To a solution of 7-chloro-1,2,3,4-tetrahydro-benzo[b]azepin-5-one (5 g, $0.0303 \mathrm{~mol})$ at $0^{\circ} \mathrm{C}$ in $40 \mathrm{~mL}$ methylene dichloride triethyl amine $(10.1 \mathrm{~mL}, 0.0727 \mathrm{~mol})$ was added dropwise. Reaction mixture was stirred at room temperature for 15 minutes. $o$-Toluoyl chloride $(4.174 \mathrm{~mL}, 0.0302 \mathrm{~mol})$ was charged and the resulting reaction mixture was stirred for $2 \mathrm{~h}$. Reaction mixture was washed with demineralized water $(40 \mathrm{~mL})$ and then with dilute hydrochloric acid $(40 \mathrm{~mL}, 10 \%)$. Organic layer was separated and dried over sodium sulfate and distilled under vacuum to get product as light yellow solid (Scheme 2).

$(5.5 \mathrm{~g}$, Yield $=58 \%)$. HPLC purity $=99.33 \%, \mathrm{MS} \mathrm{m} / \mathrm{z}=$ $314.17(\mathrm{M}+\mathrm{H}),{ }^{1} \mathrm{H}$ NMR $\left(300 \mathrm{MHz}, \mathrm{DMSO}_{\mathrm{d}}, \delta / \mathrm{ppm}\right) 7.56-$ $6.93(7 \mathrm{H}, m), 3.6-3.3(2 \mathrm{H}, m), 2.3(3 \mathrm{H}, s), 2.1-1.9(2 \mathrm{H}, m)$, $1.04-1.02(2 \mathrm{H}, m)$.

2.2.2. Preparation of Tolvaptan Impurity B. To a solution of $\mathrm{A}(3 \mathrm{~g}, 0.00958 \mathrm{~mol})$ at $0^{\circ} \mathrm{C}$ in $30 \mathrm{~mL}$ methanol sodium borohydride $(0.181 \mathrm{~g}, 0.004 \mathrm{~mol})$ was added portionwise. Reaction mixture was stirred for half an hour at the same temperature. Solvent of the reaction mixture distilled under vacuum. $40 \mathrm{~mL}$ MDC was added to the residue. It was then washed with water $(40 \mathrm{~mL})$ and with dil. $\mathrm{HCl}(40 \mathrm{~mL}, 10 \%)$. Organic layer was separated and dried over sodium sulfate and distilled under vacuum to get product as white solid (Scheme 3).

$(2.5 \mathrm{~g}, \%$ Yield $=83 \%)$. HPLC purity $=96.87 \%, \mathrm{MS} \mathrm{m} / z=$ $316.19(\mathrm{M}+\mathrm{H}),{ }^{1} \mathrm{H}$ NMR $\left(300 \mathrm{MHz}, \mathrm{DMSO}_{\mathrm{d}}, \delta / \mathrm{ppm}\right) 7.57-$ $6.93(7 \mathrm{H}, m), 4.0(1 \mathrm{H}, m), 3.6-3.3(3 \mathrm{H}, m), 2.4(3 \mathrm{H}, s), 2.1-1.9$ $(2 \mathrm{H}, m), 1.04-1.02(2 \mathrm{H}, m)$.

2.2.3. Preparation of Tolvaptan Impurity C. To a solution of 2-methyl 4-amino benzoic acid ( $5 \mathrm{~g}, 0.0331 \mathrm{~mol})$ in $\mathrm{MDC}$ $(40 \mathrm{~mL})$ at $0^{\circ} \mathrm{C}$ triethyl amine $(10.1 \mathrm{~mL}, 0.0727 \mathrm{~mol})$ was added dropwise. Reaction mixture was stirred at room temperature for 15 minutes. $o$-Toluoyl chloride $(4.320 \mathrm{~mL}$, $0.0330 \mathrm{~mol}$ ) was added to the reaction mixture. Reaction mixture was stirred for 2 hours. RM was washed with DM water $(40 \mathrm{~mL})$ and with dilute $\mathrm{HCl}(40 \mathrm{~mL}, 10 \%)$. Organic layer was separated and dried over sodium sulfate. Methanol was also added to dissolve the undissolved particles. Solvent distilled under vacuum to get the crude as light yellow solid product which is then washed with ethyl acetate $(30 \mathrm{~mL})$ to get product as white solid (Scheme 4).

$(4 \mathrm{~g}, \%$ Yield $=45 \%)$ HPLC purity $=95.71 \%, \mathrm{MS} \mathrm{m} / \mathrm{z}=$ $270.19(\mathrm{M}+\mathrm{H}),{ }^{1} \mathrm{H}$ NMR $\left(300 \mathrm{MHz}, \mathrm{DMSO}_{-}, \mathrm{d}_{6}, \delta / \mathrm{ppm}\right) 12.5$ 


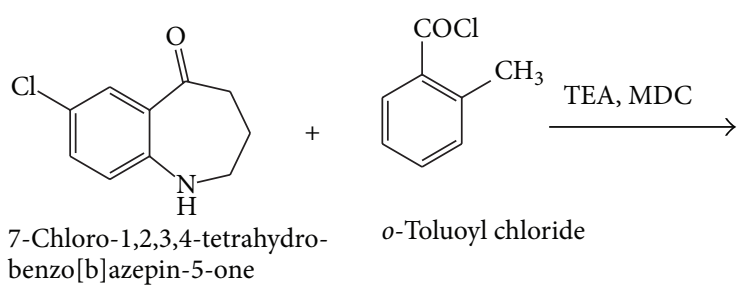<smiles>Cc1ccccc1C(=O)N1CCCC(=O)c2cc(Cl)ccc21</smiles>

Scheme 2: Synthetic route for Impurity A.<smiles>Cc1ccccc1C(=O)N1CCCC(=O)c2cc(Cl)ccc21</smiles>

Impurity A

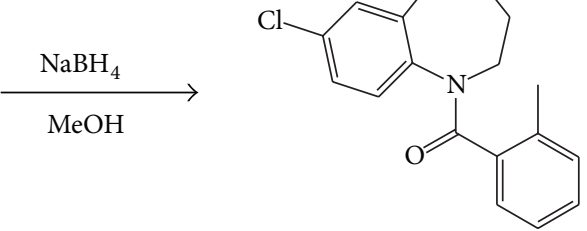

Impurity B

SCHEME 3: Synthetic route for Impurity B.

$(1 \mathrm{H}, s), 10.3(1 \mathrm{H}, s), 7.87-7.84(1 \mathrm{H}, m), 7.68-7.65(2 \mathrm{H}, m), 7.47-$ $7.38(2 \mathrm{H}, m), 7.33-7.28(2 \mathrm{H}, m), 2.52-2.49(3 \mathrm{H}, m), 2.38(3 \mathrm{H}$, s).

\subsubsection{Preparation of Tolvaptan Impurity D. To a solution} of compound with formula $\mathrm{C}(3 \mathrm{~g}, 0.0091 \mathrm{~mol})$ in methanol $(40 \mathrm{~mL})$ at $0^{\circ} \mathrm{C}$ sodium borohydride $(0.3 \mathrm{~g}, 0.000126 \mathrm{~mol})$ was added portionwise. The reaction mixture was stirred at the same temperature for $0.5 \mathrm{~h}$. Solvent of the reaction mixture distilled under vacuum. MDC was added to the residue $(40 \mathrm{~mL})$. The $\mathrm{RM}$ was washed with water $(40 \mathrm{~mL})$ and with dil. $\mathrm{HCl}(40 \mathrm{~mL}, 10 \%)$. Organic layer was separated and dried over sodium sulfate and distilled under vacuum to get product as light yellow solid (Scheme 5).

$(2.5 \mathrm{~g}, \%$ Yield $=83 \%)$ HPLC purity $=91.66 \%, \mathrm{MS} \mathrm{m} / \mathrm{z}$ $=331.0(\mathrm{M}+\mathrm{H}){ }^{1} \mathrm{H}$ NMR $\left(300 \mathrm{MHz}, \mathrm{DMSO}-\mathrm{d}_{6}, \delta / \mathrm{ppm}\right)$ 1.44-1.77 (2H, m), 1.94-2.11 (2H, m), $2.19(3 \mathrm{H}, s), 2.65-2.73$ $(2 \mathrm{H}, m), 4.80-4.92(1 \mathrm{H}, m), 5.30(2 \mathrm{H}, m), 5.72(1 \mathrm{H}, d, J=$ $7 \mathrm{~Hz}), 6.10-7.6(6 \mathrm{H}, m)$.

2.2.5. Preparation of Tolvaptan Impurity E. To a solution of Tolvaptan pharma $(2 \mathrm{~g}, 0.00447 \mathrm{~mol})$ in MDC $(40 \mathrm{~mL})$ otoluoyl chloride $(2.4 \mathrm{~mL}, 0.0200 \mathrm{~mol})$ was added. Reaction mixture was stirred for 24 hours. Solvent distilled under vacuum to get the crude as light yellow solid product purified by column chromatography (Hexane: Ethyl acetate) (Scheme 6).

$(800 \mathrm{mg}, \%$ Yield $=32 \%)$ HPLC purity $=91.5 \%, \mathrm{MS} \mathrm{m} / \mathrm{z}$ $=567.20(\mathrm{M}+\mathrm{H}),{ }^{1} \mathrm{H}$ NMR $\left(300 \mathrm{MHz}, \mathrm{DMSO}_{-} \mathrm{d}_{6}, \delta / \mathrm{ppm}\right)$ $1.46-1.75(2 \mathrm{H}, m), 1.93-2.02(1 \mathrm{H}, m), 2.05-2.12(1 \mathrm{H}, m)$, 2.64-2.73 (1H, m), $2.26(6 \mathrm{H}, s), 2.30(3 \mathrm{H}, s), 4.83-4.87(1 \mathrm{H}$, $m), 5.70(1 \mathrm{H}, s), 6.59(1 \mathrm{H}, d), 6.79-6.96(2 \mathrm{H}, d, J=7.2 \mathrm{~Hz})$, $7.11-7.42(8 \mathrm{H}, m), 7.54-7.66(2 \mathrm{H}, m)$.
2.2.6. Preparation of Tolvaptan Impurity F. To a solution of 4-nitro benzoic acid ( $11 \mathrm{~g}, 0.0658 \mathrm{~mol})$ in toluene $(100 \mathrm{~mL})$ and $N, N$ dimethylformamide $(3 \mathrm{~mL})$ at $0^{\circ} \mathrm{C}$ thionyl chloride $(7.2 \mathrm{~mL}, 0.0949 \mathrm{~mol})$ was added dropwise. Reaction mixture was heated $60^{\circ} \mathrm{C}$ for 45 minutes. Solvent and excess thionyl chloride was distilled under reduced pressure. To a solution of 7-chloro-1, 2, 3, 4-tetrahydro-benzo[b]azepin-5one $(9.78 \mathrm{~g}, 0.0592 \mathrm{~mol})$ in MDC $(100 \mathrm{~mL})$, triethyl amine $(27 \mathrm{~mL}, 0.197 \mathrm{~mol})$ was added and stirred for 15 minutes. The isolated acid chloride of 4-nitro benzoic acid was added to the reaction mixture and stirred for $2 \mathrm{~h}$. RM was washed with DM water $(100 \mathrm{~mL})$ and with dilute $\mathrm{HCl}(100 \mathrm{~mL}, 10 \%)$. Organic layer was separated, dried over sodium sulfate, and distilled under vacuum to get product as light yellow solid (Scheme 7).

(Yield $=15 \mathrm{~g}, \%$ Yield $=66 \%$ ). HPLC purity $=91.34 \%$, MS $m / z=345.0(\mathrm{M}+\mathrm{H}),{ }^{1} \mathrm{H}$ NMR $\left(300 \mathrm{MHz}, \mathrm{DMSO}-\mathrm{d}_{6}\right.$, $\delta / \mathrm{ppm})$ 8.5-8.4 $(2 \mathrm{H}, m), 8.4-8.2(2 \mathrm{H}, m), 7.6-7.4(3 \mathrm{H}, m)$, $3.0-2.5(4 \mathrm{H}, m), 1.3-1.0(2 \mathrm{H}, m)$.

2.2.7. Preparation of Tolvaptan Impurity G. To a solution of $\mathrm{F}(7 \mathrm{~g}, 0.0203 \mathrm{~mol})$ in ethanol $(50 \mathrm{~mL}) \mathrm{SnCl}_{2}(13.7 \mathrm{~g}$, $0.0610 \mathrm{~mol}$ ) was added. Reaction mixture cooled to $0^{\circ} \mathrm{C}$ and conc. $\mathrm{HCl}(23 \mathrm{~mL})$ was added dropwise. RM was stirred at room temperature for 16 hours. Reaction mixture was poured into crushed ice $(100 \mathrm{~mL}) . \mathrm{pH}$ of the solution was adjusted to 9 using sodium hydroxide solution. Ethyl acetate $(100 \mathrm{~mL})$ was added to it and stirred for 30 minutes. Organic layer was separated, dried over sodium sulfate, and concentrated under vacuum to get product as light yellow solid (Scheme 8). (6.1 g, $\%$ Yield $=95 \%)$. HPLC purity $=90.9 \%$, MS $m / z=315.0(\mathrm{M}+$ H) ${ }^{1} \mathrm{H}$ NMR $\left(300 \mathrm{MHz}, \mathrm{DMSO}-\mathrm{d}_{6}, \delta / \mathrm{ppm}\right) 8.4-8.0(2 \mathrm{H}, m)$, 7.6-7.2 (2H, $m), 7.0-6.8(3 \mathrm{H}, m), 5.2(2 \mathrm{H}, s), 3.0-2.5(4 \mathrm{H}, m)$, $1.3-1.0(2 \mathrm{H}, m)$. 
4

Advances in Chemistry<smiles>Cc1cc(N)ccc1C(=O)O</smiles><smiles>Cc1ccccc1C(=O)Cl</smiles><smiles>Cc1cc(NC(=O)c2ccccc2C)ccc1C(=O)O</smiles>

2-Methyl 4-amino benzoic acid

$o$-Toluoyl chloride

Impurity C

Scheme 4: Synthetic route for Impurity C.<smiles>Cc1cc(N)ccc1C(=O)N1CCCC(=O)c2cc(Cl)ccc21</smiles>

TLV-2

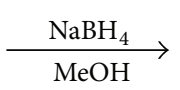<smiles>Cc1cc(N)ccc1C(=O)N1CCCC(O)c2cc(Cl)ccc21</smiles>

Impurity D

Scheme 5: Synthetic route for Impurity D.

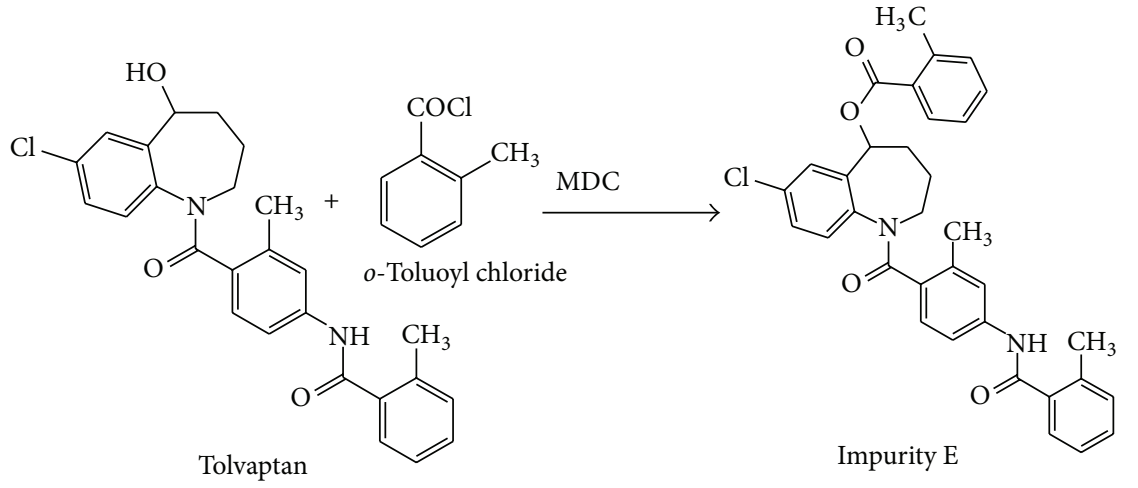

Scheme 6: Synthetic route for impurity E.<smiles>O=C(O)c1ccc([N+](=O)[O-])cc1</smiles>

4-Nitro benzoic acid

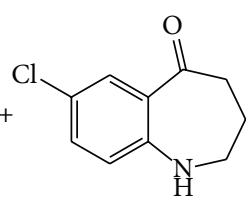

7-Chloro-1,2,3,4-tetrahydrobenzo[b]azepin-5-one

4-Nitro

benzoyl chloride

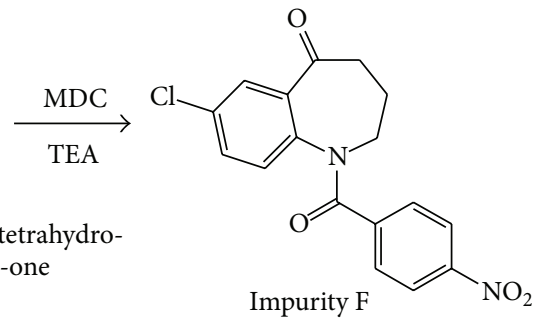

Impurity $\mathrm{F}$

Scheme 7: Synthetic route for Impurity F.

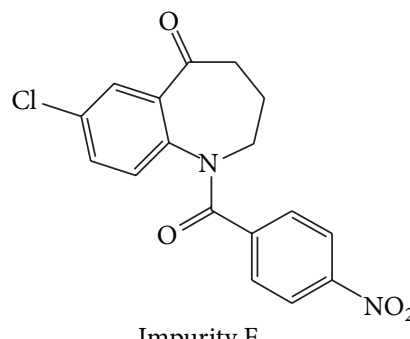

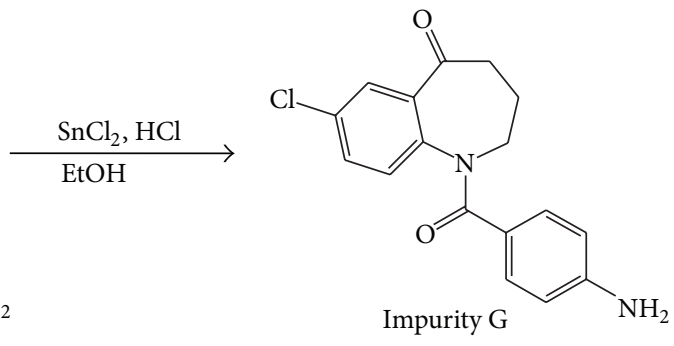<smiles>Nc1ccc(C(=O)N2CCCC(=O)c3cc(Cl)ccc32)cc1</smiles>

Impurity $\mathrm{F}$

Scheme 8: Synthetic route for Impurity G. 
2.2.8. Preparation of Tolvaptan Impurity $H$. To a solution of $\mathrm{G}(5 \mathrm{~g}, 0.00318 \mathrm{~mol})$ in $\mathrm{MDC}(40 \mathrm{~mL})$ at $0^{\circ} \mathrm{C}$ triethyl amine $(6.6 \mathrm{~mL}, 0.0473 \mathrm{~mol})$ was added dropwise. Reaction mixture was stirred at room temperature for 45 minutes. $o$-Toluoyl chloride $(2.5 \mathrm{~mL}, 0.0191 \mathrm{~mol})$ was added to the reaction mixture and stirred for $1 \mathrm{~h}$. Reaction mixture was washed with DM water $(40 \mathrm{~mL})$ and with dilute $\mathrm{HCl}(40 \mathrm{~mL}$, $10 \%)$. Organic layer was separated, dried over sodium sulfate, and distilled under vacuum to get product as light yellow solid (Scheme 9).

$(6 \mathrm{~g}, \%$ Yield $=87 \%)$. HPLC purity $=92.94 \%, \mathrm{MS} m / z=$ $433.0(\mathrm{M}+\mathrm{H}),{ }^{1} \mathrm{H}$ NMR $\left(300 \mathrm{MHz}, \mathrm{DMSO}_{6}, \delta / \mathrm{ppm}\right) 10.5$ $(1 \mathrm{H}, s), 7.7-7.6(3 \mathrm{H}, m), 7.4-7.3(3 \mathrm{H}, m), 7.2-7.1(4 \mathrm{H}, m), 6.9-6.8$ $(1 \mathrm{H}, m), 4.5-4.0(1 \mathrm{H}, m), 2.7(1 \mathrm{H}, s), 2.4(3 \mathrm{H}, s), 2.0-1.9(2 \mathrm{H}$, $m), 1.3-1.2(1 \mathrm{H}, m)$.

2.2.9. Preparation of Tolvaptan Impurity I. To a solution of $\mathrm{H}(4 \mathrm{~g}, 0.009 \mathrm{~mol})$ in methanol $(40 \mathrm{~mL})$ at $0^{\circ} \mathrm{C}$ sodium borohydride $(0.175 \mathrm{~g}, 0.00462)$ was added portionwise. The reaction mixture was stirred at the same temperature for $0.5 \mathrm{~h}$. Solvent of the reaction mixture was distilled under vacuum. $40 \mathrm{ml} \mathrm{MDC}$ was added to the residue. It was washed with water $(40 \mathrm{~mL})$ and with dil. $\mathrm{HCl}(40 \mathrm{~mL})$. Organic layer was separated, dried over sodium sulfate, and distilled under vacuum to get product as white solid (Scheme 10).

$(2.5 \mathrm{~g}, \%$ Yield $=62 \%)$. HPLC purity $=94.37 \%, \mathrm{MS} \mathrm{m} / \mathrm{z}=$ $435.1(\mathrm{M}+\mathrm{H}),{ }^{1} \mathrm{H}$ NMR $\left(300 \mathrm{MHz}, \mathrm{DMSO}-\mathrm{d}_{6}, \delta / \mathrm{ppm}\right) 10.4$ $(1 \mathrm{H}, s), 7.6-7.5(3 \mathrm{H}, m), 7.4-7.3(3 \mathrm{H}, m), 7.1-7.0(4 \mathrm{H}, m), 6.9-6.8$ $(1 \mathrm{H}, m), 4.5-4.0(1 \mathrm{H}, m), 3.8-3.6(1 \mathrm{H}, m), 3.4-3.3(1 \mathrm{H}, m), 2.7$ $(1 \mathrm{H}, s), 2.4(3 \mathrm{H}, s), 2.0-1.9(2 \mathrm{H}, m), 1.3-1.2(1 \mathrm{H}, m)$.

2.2.10. Preparation of Tolvaptan Impurity J. To a solution of 4methyl benzoic acid $(3 \mathrm{~g}, 0.0220 \mathrm{~mol})$ in toluene $(20 \mathrm{~mL})$ and DMF $(0.2 \mathrm{~mL})$ at $0^{\circ} \mathrm{C}$ thionyl chloride $(2.5 \mathrm{~mL}, 0.0210 \mathrm{~mol})$ was added dropwise. Reaction mixture was heated $60^{\circ} \mathrm{C}$ for 30 minutes. Solvent and excess thionyl chloride was distilled under reduced pressure. In another reaction, to a solution of TLV-2 (5 g, $0.0152 \mathrm{~mol})$ MDC (20 mL) triethyl amine $(6 \mathrm{~mL})$ was added. Isolated acid chloride of 4-methyl benzoic acid was added to the reaction mixture. Reaction mixture was stirred for 45 minutes. RM was washed with DM water $(30 \mathrm{~mL})$ and with dilute $\mathrm{HCl}(30 \mathrm{~mL}, 10 \%)$. Organic layer was separated, dried over sodium sulfate, and distilled under vacuum to get product as light yellow solid (Scheme 11).

$(6 \mathrm{~g}, \%$ Yield $=61 \%)$. HPLC purity $=81.66 \%$, which is further purified by flash column chromatography. MS $m / z=$ $447.1(\mathrm{M}+\mathrm{H}),{ }^{1} \mathrm{H}$ NMR (300 MHz, DMSO-d 6 , $\left.\delta / \mathrm{ppm}\right) 1.99$ $(2 \mathrm{H}, m), 2.30(3 \mathrm{H}, s), 2.35(3 \mathrm{H}, s), 2.80(2 \mathrm{H}, m), 3.71(2 \mathrm{H}, m)$, 7.25-7.44 (7H, m), 7.61-7.65 (1H, m), $10.29(1 \mathrm{H}, s)$.

2.2.11. Preparation of Tolvaptan Impurity K. To a solution of $\mathrm{J}$ $(1.5 \mathrm{~g}, 0.0033 \mathrm{~mol})$ in methanol $(20 \mathrm{~mL})$ at $0^{\circ} \mathrm{C}$ sodium borohydride $(0.38 \mathrm{~g}, 0.0100 \mathrm{~mol})$ was added portionwise. Reaction mixture was stirred at the same temperature for $0.5 \mathrm{~h}$. Solvent of the reaction mixture was distilled under vacuum. MDC was added to the residue $(30 \mathrm{~mL})$ and then washed with water $(30 \mathrm{~mL})$ and with dil. $\mathrm{HCl}(30 \mathrm{~mL})$. Organic layer was separated, dried over sodium sulfate, and distilled under vacuum to get product as white solid (Scheme 12).
(900 mg, \% Yield $=60 \%)$. HPLC purity $=84.61 \%, \mathrm{MS} \mathrm{m} / z$ $=449.1(\mathrm{M}+\mathrm{H}),{ }^{1} \mathrm{H}$ NMR $\left(300 \mathrm{MHz}, \mathrm{DMSO}_{-} \mathrm{d}_{6}, \delta / \mathrm{ppm}\right) 1.95$ $(2 \mathrm{H}, m), 2.30(3 \mathrm{H}, s), 2.35(3 \mathrm{H}, s), 2.80(2 \mathrm{H}, m), 3.71-3.95(3 \mathrm{H}$, $m), 5.41(1 \mathrm{H}, d, J=7.1 \mathrm{~Hz}), 7.25-7.44(7 \mathrm{H}, m), 7.61-7.65(1 \mathrm{H}, m)$, $10.29(1 \mathrm{H}, s)$.

2.2.12. Preparation of Tolvaptan Impurity L. To a solution of 3-methyl benzoic acid $(2 \mathrm{~g}, 0.0146 \mathrm{~mol})$ in toluene $(20 \mathrm{~mL})$ and $\mathrm{DMF}(0.2 \mathrm{~mL})$ at $0^{\circ} \mathrm{C}$ thionyl chloride $(1.7 \mathrm{~mL}$, $0.0142 \mathrm{~mol}$ ) was added dropwise. Reaction mixture was heated to $60^{\circ} \mathrm{C}$ for 30 minutes. Solvent and excess thionyl chloride was distilled under reduced pressure. In another reaction, to solution of TLV-2 $(5 \mathrm{~g}, 0.0152 \mathrm{~mol})$ in $\mathrm{MDC}$ $(20 \mathrm{~mL})$ triethyl amine $(5 \mathrm{~mL})$ was added and stirred for 15 minutes. Isolated acid chloride of 3-methyl benzoic acid was added to the reaction mixture and stirred for 45 minutes. RM was washed with DM water $(30 \mathrm{~mL})$ and with dilute $\mathrm{HCl}$ (30 mL, 10\%). Organic layer was separated, dried over sodium sulfate, and distilled under vacuum to get product as light yellow solid (Scheme 13).

$(4 \mathrm{~g}, \%$ Yield $=61 \%)$. HPLC purity $=79.2 \%$ which is further purified by flash column chromatography, MS $\mathrm{m} / z=$ $447.1(\mathrm{M}+\mathrm{H}),{ }^{1} \mathrm{H}$ NMR $\left(300 \mathrm{MHz}, \mathrm{DMSO}_{6}, \delta / \mathrm{ppm}\right) 1.99$ $(2 \mathrm{H}, m), 2.30(3 \mathrm{H}, s), 2.35(3 \mathrm{H}, s), 2.80(2 \mathrm{H}, m), 3.71(2 \mathrm{H}, m)$, 7.25-7.44 (7H, m), 7.51-7.60 (1H, m), $10.32(1 \mathrm{H}, s)$.

2.2.13. Preparation of Tolvaptan Impurity $M$. To a solution of $\mathrm{L}(1.5 \mathrm{~g}, 0.0033 \mathrm{~mol})$ in methanol $(20 \mathrm{~mL})$ at $0^{\circ} \mathrm{C}$ sodium borohydride $(0.38 \mathrm{~g}, 0.0102 \mathrm{~mol})$ was added portionwise. Solvent of the reaction mixture was distilled under vacuum. MDC $(40 \mathrm{~mL})$ was added to the residue and washed with water $(40 \mathrm{~mL})$ and with dil. $\mathrm{HCl}(40 \mathrm{~mL})$. Organic layer was separated, dried over sodium sulfate, and distilled under vacuum to get product as light yellow solid (Scheme 14).

$(1.0 \mathrm{~g}, \%$ Yield $=66 \%), \mathrm{MS} m / z=449.1(\mathrm{M}+\mathrm{H}) ;{ }^{1} \mathrm{H}$ NMR (300 MHz, DMSO-d 6 , $\delta / p p m) 1.98(2 \mathrm{H}, m), 2.28(3 \mathrm{H}, s), 2.35$ $(3 \mathrm{H}, s), 2.80(2 \mathrm{H}, m), 3.71-3.95(3 \mathrm{H}, m), 5.41(1 \mathrm{H}, d, J=7.1 \mathrm{~Hz})$, 7.28-7.44 (7H, m), 7.60-7.65 (1H, $m), 10.32(1 \mathrm{H}, s)$.

2.2.14. Preparation of Tolvaptan Impurity $N$. To a solution of 3,4-dimethyl benzoic acid (3.5 g, $0.0233 \mathrm{~mol}$ ) in toluene $(30 \mathrm{~mL})$ and $\mathrm{DMF}(1 \mathrm{~mL})$ at $0^{\circ} \mathrm{C}$ thionyl chloride $(4.1 \mathrm{~mL}$, $0.0344 \mathrm{~mol}$ ) was added dropwise. Reaction mixture was heated to $60^{\circ} \mathrm{C}$ for 45 minutes. Solvent and excess thionyl chloride was distilled under reduced pressure. In another reaction, to a solution TLV-2 $(5 \mathrm{~g}, 0.0152 \mathrm{~mol})$ in $\mathrm{MDC}$ $(30 \mathrm{~mL})$ triethyl amine $(6 \mathrm{~mL}, 0.0810 \mathrm{~mol})$ was added. The reaction mixture was stirred for 15 minutes. The isolated acid chloride of 3,4-dimethyl benzoic acid was added to the reaction mixture. Reaction mixture stirred for 45 minutes at room temperature. RM was washed with $\mathrm{DM}$ water $(30 \mathrm{~mL})$ and with dilute $\mathrm{HCl}(30 \mathrm{~mL}, 10 \%)$ Organic layer was separated, dried over sodium sulfate, and distilled under vacuum to get product as yellow solid (Scheme 15).

$(7 \mathrm{~g}, \%$ Yield $=65 \%)$. HPLC purity $=71.5 \%$, which is further purified by flash column chromatography, MS $\mathrm{m} / z=$ $461.1(\mathrm{M}+\mathrm{H}) ;{ }^{1} \mathrm{H}$ NMR (300 MHz, DMSO-d 6 , $\left.\delta / \mathrm{ppm}\right) 2.00$ $(2 \mathrm{H}, m), 2.30(3 \mathrm{H}, s), 2.35(3 \mathrm{H}, s), 2.40(3 \mathrm{H}, s), 2.85(2 \mathrm{H}, m)$, 
6

Advances in Chemistry<smiles>Nc1ccc(C(=O)N2CCCC(=O)c3cc(Cl)ccc32)cc1</smiles>

Impurity G<smiles>Cc1ccccc1C(=O)Nc1ccc(C(=O)N2CCCC(=O)c3cc(Cl)ccc32)cc1</smiles>

Scheme 9: Synthetic route for Impurity H.<smiles>Cc1ccccc1C(=O)Nc1ccc(C(=O)N2CCCC(O)c3cc(Cl)ccc32)cc1</smiles>

Impurity $\mathrm{H}$

Impurity I

Scheme 10: Synthetic route for Impurity I.

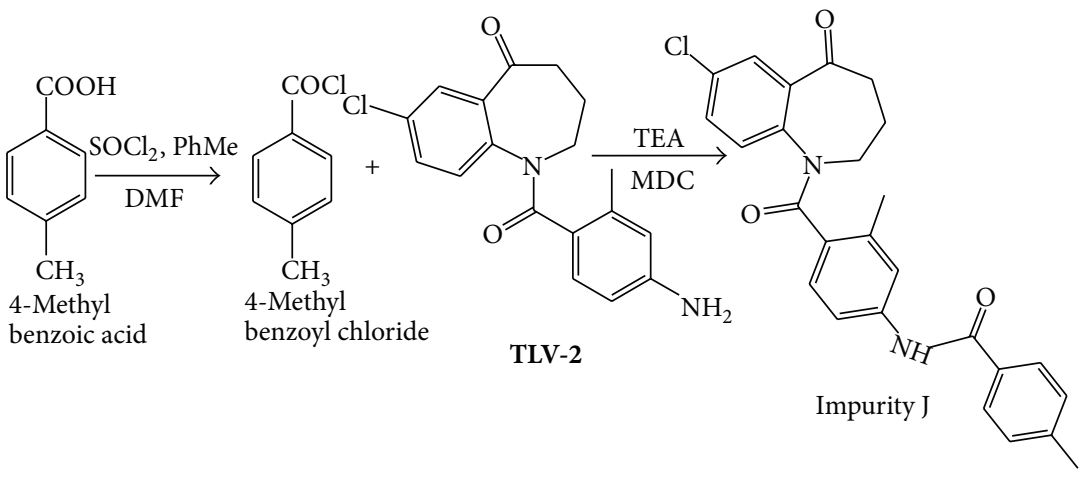

SCHEME 11: Synthetic route for Impurity J.<smiles>Cc1ccc(C(=O)Nc2ccc(C(=O)N3CCCC(O)c4cc(Cl)ccc43)c(C)c2)cc1</smiles>

SCHEME 12: Synthetic route for Impurity K. 


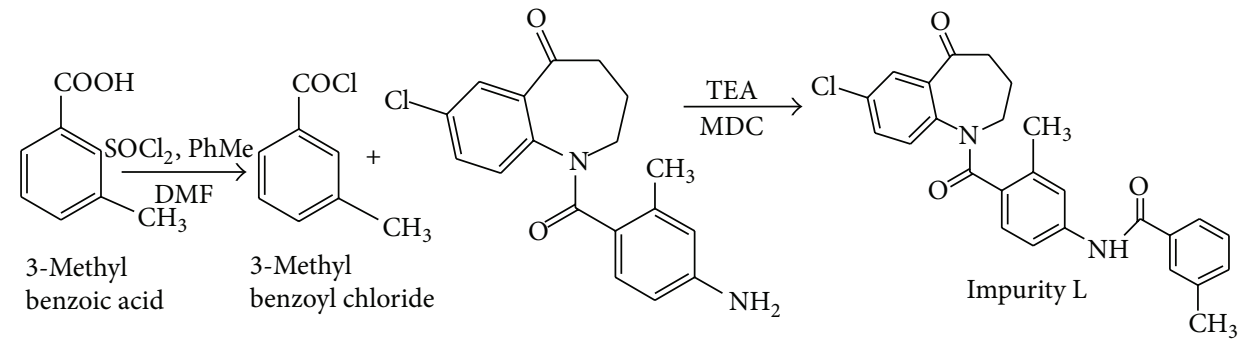

TLV-2

SCHEME 13: Synthetic route for Impurity L.<smiles>Cc1cccc(C(=O)Nc2ccc(C(=O)N3CCCC(O)c4cc(Cl)ccc43)c(C)c2)c1</smiles>

SCHEME 14: Synthetic route for Impurity M.

$3.78(2 \mathrm{H}, m), 7.25-7.44(6 \mathrm{H}, m), 7.51-7.60(1 \mathrm{H}, m), 10.28(1 \mathrm{H}$, s).

2.2.15. Preparation of Tolvaptan Impurity $O$. To a solution of $\mathrm{N}(1.5 \mathrm{~g}, 0.0033 \mathrm{~mol})$ in methanol $(20 \mathrm{~mL})$ at $0^{\circ} \mathrm{C}$ sodium borohydride $(0.38 \mathrm{~g}, 0.00978 \mathrm{~mol})$ was added portionwise. Solvent of the reaction mixture was distilled under vacuum. MDC was added to the residue $(30 \mathrm{~mL})$ and washed with water $(30 \mathrm{~mL})$ and with dil. $\mathrm{HCl}(30 \mathrm{~mL})$. Organic layer was separated, dried over sodium sulfate, and distilled under vacuum to get product as light yellow solid (Scheme 16).

$(800 \mathrm{mg}, \%$ Yield $=53 \%)$, MS $m / z=463.1(\mathrm{M}+\mathrm{H}){ }^{1} \mathrm{H}$ NMR (300 MHz, DMSO-d 6 , $\delta / \mathrm{ppm}) 2.00(2 \mathrm{H}, m), 2.30(3 \mathrm{H}$, $s), 2.35(3 \mathrm{H}, s), 2.40(3 \mathrm{H}, s), 2.85(3 \mathrm{H}, m), 3.78(2 \mathrm{H}, m), 5.41$ $(1 \mathrm{H}, d, J=7.3 \mathrm{~Hz}), 7.25-7.44(6 \mathrm{H}, m), 7.51-7.60(1 \mathrm{H}, m), 10.25$ $(1 \mathrm{H}, s)$.

2.2.16. Preparation of Tolvaptan Impurity $P$. To a solution of 2,4-dimethyl benzoic acid $(3.0 \mathrm{~g}, 0.0199 \mathrm{~mol})$ in toluene $(30 \mathrm{~mL})$ and DMF $(1 \mathrm{~mL})$ at $0^{\circ} \mathrm{C}$ thionyl chloride $(3.2 \mathrm{~mL}$, $0.0294 \mathrm{~mol}$ ) was added dropwise. Reaction mixture was heated $60^{\circ} \mathrm{C}$ for 45 minutes. Solvent and excess thionyl chloride was distilled under reduced pressure. In another reaction, to a solution of TLV-2 $(4 \mathrm{~g}, 0.0121 \mathrm{~mol})$ in MDC $(30 \mathrm{~mL})$ triethyl amine $(6 \mathrm{~mL}, 0.0810 \mathrm{~mol})$ was added. Isolated acid chloride of 2,4-dimethyl benzoic acid was added to the reaction mixture and stirred for 45 minutes. RM was washed with DM water $(30 \mathrm{~mL})$ and with dilute $\mathrm{HCl}(30 \mathrm{~mL}$, $10 \%)$. Organic layer was separated, dried over sodium sulfate, and distilled under vacuum to get product as yellow solid (Scheme 17).
$(5 \mathrm{~g}, \%$ Yield $=54 \%)$. HPLC purity $=78.3 \%$ which is further purified by flash column chromatography, MS $\mathrm{m} / z=$ $461.1(\mathrm{M}+\mathrm{H}){ }^{1} \mathrm{H}$ NMR $\left(300 \mathrm{MHz}, \mathrm{DMSO}-\mathrm{d}_{6}, \delta / \mathrm{ppm}\right) 2.05$ $(2 \mathrm{H}, m), 2.32(3 \mathrm{H}, s), 2.35(3 \mathrm{H}, s), 2.40(3 \mathrm{H}, s), 2.85(2 \mathrm{H}, m)$, $3.78(2 \mathrm{H}, m), 7.25-7.48(6 \mathrm{H}, m), 7.50-7.65(1 \mathrm{H}, m), 10.29(1 \mathrm{H}$, s).

2.2.17. Preparation of Tolvaptan Impurity Q. To a solution of $\mathrm{P}(2.2 \mathrm{~g}, 0.00478 \mathrm{~mol})$ in methanol $(30 \mathrm{~mL})$ at $0^{\circ} \mathrm{C}$ sodium borohydride $(0.542 \mathrm{~g}, 0.01432 \mathrm{~mol})$ was added portionwise. Reaction mixture was stirred for $0.5 \mathrm{~h}$. Solvent of the reaction mixture distilled under vacuum. MDC was added to the residue $(20 \mathrm{~mL})$ and washed with water $(20 \mathrm{~mL})$ and with dil. $\mathrm{HCl}(20 \mathrm{~mL})$. Organic layer was separated, dried over sodium sulfate, and distilled under vacuum to get product as light yellow solid (Scheme 18).

$(1.2 \mathrm{~g}, \%$ Yield $=54 \%)$. HPLC purity $=88.77 \%, \mathrm{MS} \mathrm{m} / \mathrm{z}$ $=463.1(\mathrm{M}+\mathrm{H}){ }^{1} \mathrm{H}$ NMR $\left(300 \mathrm{MHz}, \mathrm{DMSO}-\mathrm{d}_{6}, \delta / \mathrm{ppm}\right)$ $2.10(2 \mathrm{H}, m), 2.30(3 \mathrm{H}, s), 2.35(3 \mathrm{H}, s), 2.40(3 \mathrm{H}, s), 2.87(3 \mathrm{H}$, $m), 3.78(2 \mathrm{H}, m), 5.42(1 \mathrm{H}, d, J=7.1 \mathrm{~Hz}), 7.23-7.44(6 \mathrm{H}, m)$, 7.51-7.68 $(1 \mathrm{H}, m), 10.25(1 \mathrm{H}, s)$.

2.2.18. Preparation of Tolvaptan Impurity $R$. To a solution of 2,-methyl 4-nitro benzoic acid $(10 \mathrm{~g}, 0.0552 \mathrm{~mol})$ in toluene $(100 \mathrm{~mL})$ and DMF $(3 \mathrm{~mL})$ at $0^{\circ} \mathrm{C}$ thionyl chloride $(8.9 \mathrm{~mL}$, $0.0828 \mathrm{~mol}$ ) was added dropwise. Reaction mixture was heated $60^{\circ} \mathrm{C}$ for 45 minutes. Solvent and excess thionyl chloride distilled under reduced pressure. In another reaction, to a solution of 1, 2, 3, 4-tetrahydro-benzo[b]azepin-5-one (6.79 g, $0.052)$ in MDC $(100 \mathrm{~mL})$ triethyl amine $(27 \mathrm{~mL})$ was added. Isolated acid chloride of 4-nitro benzoic acid was added to the 


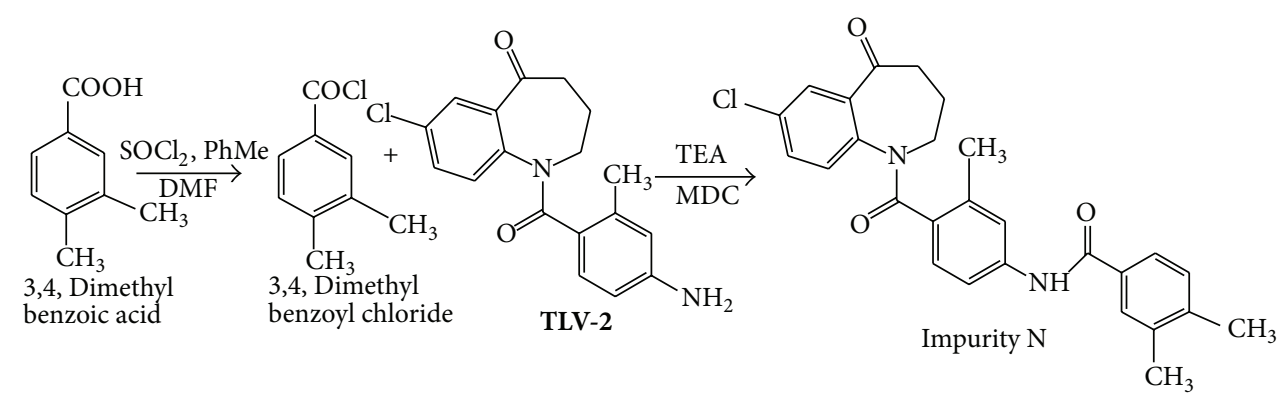

SCHEME 15: Synthetic route for Impurity N.

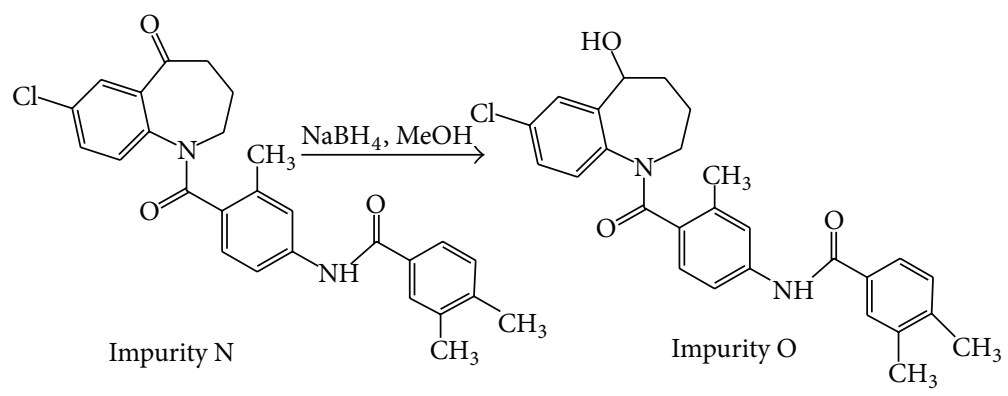

SCHEME 16: Synthetic route for Impurity O.

reaction mixture and stirred for $2 \mathrm{~h}$. RM was washed with DM water $(100 \mathrm{~mL})$ and with dilute $\mathrm{HCl}(100 \mathrm{~mL}, 10 \%)$. Organic layer was separated and dried over sodium sulfate. Solvent was distilled under vacuum to get product as light yellow solid (Scheme 19).

$(10 \mathrm{~g}, \%$ Yield $=55 \%)$. HPLC purity $=86.41 \%, \mathrm{MS} \mathrm{m} / \mathrm{z}=$ $325.11(\mathrm{M}+\mathrm{H}){ }^{1} \mathrm{H}$ NMR $\left(300 \mathrm{MHz}, \mathrm{DMSO}_{-} \mathrm{d}_{6}, \delta / \mathrm{ppm}\right) 1.98$ $(2 \mathrm{H}, m), 2.19(3 \mathrm{H}, s), 2.77(2 \mathrm{H}, t), 3.84(2 \mathrm{H}, m), 6.80-6.93(1 \mathrm{H}$, $d d, J=7.0 \mathrm{~Hz}, J=2.5 \mathrm{~Hz}), 6.99(1 \mathrm{H}, d, J=2.5 \mathrm{~Hz}), 7.10(1 \mathrm{H}, d, J$ $=7.0 \mathrm{~Hz}), 7.15(1 \mathrm{H}, d, J=7.1 \mathrm{~Hz}), 7.80-7.84(2 \mathrm{H}, d, J=7.2 \mathrm{~Hz})$, $7.89(1 \mathrm{H}, d, J=7.2 \mathrm{~Hz})$.

2.2.19. Preparation of Tolvaptan Impurity S. To a solution of $\mathrm{R}$ $(8 \mathrm{~g}, 0.0246 \mathrm{~mol})$ in ethanol $(80 \mathrm{~mL}), \mathrm{SnCl}_{2}(32 \mathrm{~g}, 0.142 \mathrm{~mol})$ was added. Reaction mixture was cooled to $0^{\circ} \mathrm{C}$ and conc. $\mathrm{HCl}(36 \mathrm{~mL})$ was added dropwise. $\mathrm{RM}$ was stirred at room temperature for 16 hours. Reaction mixture was poured into crushed ice. $\mathrm{pH}$ of the solution was adjusted to 9 using $\mathrm{NaOH}$ solution. Ethyl acetate and stirred for 30 minutes. Organic layer was separated, dried over sodium sulfate, and concentrated under vacuum to get product as light yellow solid (Scheme 20).

$(4 \mathrm{~g}, \%$ Yield $=83 \%)$. HPLC purity $=94.13 \%, \mathrm{MS} \mathrm{m} / z=$ $295.1(\mathrm{M}+\mathrm{H}){ }^{1} \mathrm{H}$ NMR (300 MHz, DMSO-d 6 , $\left.\delta / \mathrm{ppm}\right) 1.98$ $(2 \mathrm{H}, m), 2.19(3 \mathrm{H}, s), 2.77(2 \mathrm{H}, t), 3.84(2 \mathrm{H}, m), 5.30(2 \mathrm{H}$, d), 6.10-6.13 (1H, $d d, J=7.0 \mathrm{~Hz}, J=2.5 \mathrm{~Hz}), 6.32(1 \mathrm{H}, d, J$ $=2.5 \mathrm{~Hz}), 6.55(1 \mathrm{H}, d, J=7.0 \mathrm{~Hz}), 6.90(1 \mathrm{H}, d, J=7.0 \mathrm{~Hz})$, $7.40-7.44(2 \mathrm{H}, d, J=7.1 \mathrm{~Hz}), 7.59(1 \mathrm{H}, d, J=7.2 \mathrm{~Hz})$

2.2.20. Preparation of Tolvaptan Impurity $T$. To a solution of $\mathrm{S}(4 \mathrm{~g}, 0.0136 \mathrm{~mol})$ in $\mathrm{MDC}(60 \mathrm{~mL})$ at $0 \circ \mathrm{C}$ triethyl amine dropwise $(5.6 \mathrm{~mL}, 0.0408 \mathrm{~mol})$. Reaction mixture was stirred at room temperature for 45 minutes. o-Toluoyl chloride $(1.95 \mathrm{~mL}, 0.0149 \mathrm{~mol})$ was added to the reaction mixture and stirred for $1 \mathrm{~h}$. RM was washed with $\mathrm{DM}$ water $(40 \mathrm{~mL})$ and with dilute $\mathrm{HCl}(40 \mathrm{~mL}, 10 \%)$. Organic layer was separated, dried over sodium sulfate, and distilled under vacuum to get product as light yellow solid (Scheme 21).

$(4.5 \mathrm{~g}, \%$ Yield $=80 \%)$. HPLC purity $=92.16 \%, \mathrm{MS} \mathrm{m} / z=$ $413.1(\mathrm{M}+\mathrm{H}){ }^{1} \mathrm{H}$ NMR $\left(300 \mathrm{MHz}, \mathrm{DMSO}_{-} \mathrm{d}_{6}, \delta / \mathrm{ppm}\right) 1.99$ $(2 \mathrm{H}, m), 2.30(3 \mathrm{H}, s), 2.35(3 \mathrm{H}, s), 2.80(2 \mathrm{H}, m), 3.71(2 \mathrm{H}, m)$, 7.25-7.44 (7H, m), 7.51-7.60 (2H, m), $10.32(1 \mathrm{H}, s)$.

2.2.21. Preparation of Tolvaptan Impurity $U$. To a solution of $\mathrm{T}(3.5 \mathrm{~g}, 0.00849 \mathrm{~mol})$ in methanol $(45 \mathrm{~mL})$ at $0^{\circ} \mathrm{C}$ sodium borohydride $(0.157 \mathrm{~g}, 0.00424 \mathrm{~mol})$ was added portionwise. Solvent of the reaction mixture distilled under vacuum MDC was added to the residue $(40 \mathrm{~mL})$ and washed with water $(40 \mathrm{~mL})$ and with dil. $\mathrm{HCl}(40 \mathrm{~mL})$. Organic layer was separated and dried over sodium sulfate. Solvent was distilled under vacuum to get product as light yellow solid (Scheme 22).

$(3 \mathrm{~g}, \%$ Yield $=85 \%)$. HPLC purity $=95.18 \%, \mathrm{MS} \mathrm{m} / z=$ $415.2(\mathrm{M}+\mathrm{H}){ }^{1} \mathrm{H}$ NMR $\left(300 \mathrm{MHz}, \mathrm{DMSO}_{6}, \delta / \mathrm{ppm}\right) 1.98$ $(2 \mathrm{H}, m), 2.28(3 \mathrm{H}, s), 2.35(3 \mathrm{H}, s), 2.80(2 \mathrm{H}, m), 3.71-3.95(3 \mathrm{H}$, $m), 5.41(1 \mathrm{H}, d, J=7.0 \mathrm{~Hz}), 7.28-7.44(7 \mathrm{H}, m), 7.60-7.65(2 \mathrm{H}$, $m), 10.32(1 \mathrm{H}, s)$.

2.2.22. Preparation of Tolvaptan Impurity $V$. To a solution of benzoic acid $(3.0 \mathrm{~g}, 0.0245 \mathrm{~mol})$ in toluene $(30 \mathrm{~mL})$ and DMF $(0.1 \mathrm{~mL})$ at $0^{\circ} \mathrm{C}$ thionyl chloride $(2.7 \mathrm{~mL}, 0.0367 \mathrm{~mol})$ was added dropwise. Reaction mixture was heated $60^{\circ} \mathrm{C}$ for 45 minutes. Solvent and excess thionyl chloride was distilled under reduced pressure. In another reaction, to a solution 
Advances in Chemistry

9<smiles>Cc1ccc(C(=O)Nc2ccc(C(=O)N3CCCC(=O)c4cc(Cl)ccc43)c(C)c2)c(C)c1</smiles>

Scheme 17: Synthetic route for Impurity P.

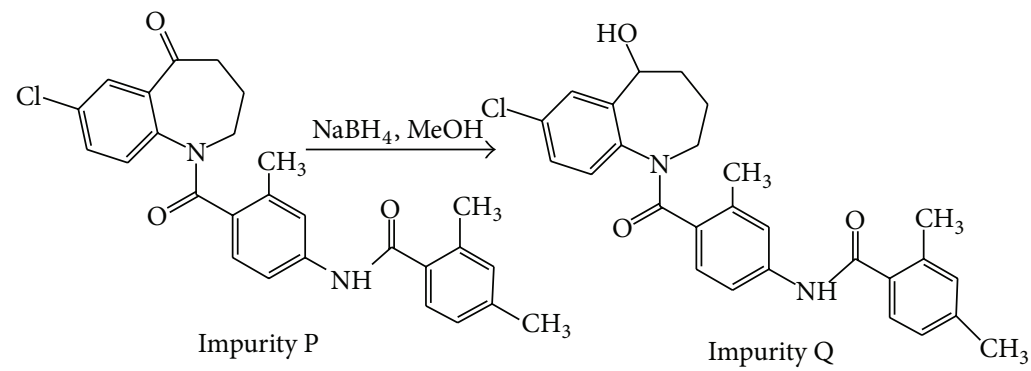

SCHeme 18: Synthetic route for Impurity Q.<smiles>Cc1cc([N+](=O)[O-])ccc1C(=O)O</smiles><smiles>Cc1cc([N+](=O)[O-])ccc1C(=O)Cl</smiles>

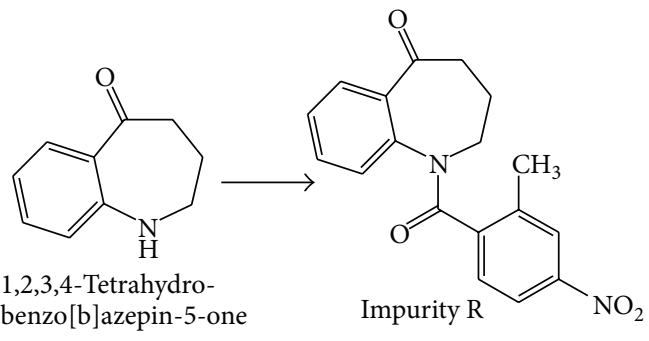

2-Methyl 4-nitro

2-Methyl 4-nitro benzoic acid benzoyl chloride benzo[b]azepin-5-one

Scheme 19: Synthetic route for Impurity R.<smiles>[R][C@H](C)[C@@H]1C(=O)c2ccccc2N(C(=O)c2ccc([N+](=O)[O-])cc2C)C1=O</smiles>

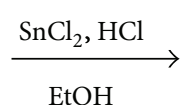

Impurity R<smiles>Cc1cc(N)ccc1C(=O)N1CCCC(=O)c2ccccc21</smiles>

Scheme 20: Synthetic route for Impurity S.<smiles>Cc1cc(N)ccc1C(=O)N1CCCC(=O)c2ccccc21</smiles><smiles>Cc1ccccc1C(=O)Nc1ccc(C(=O)N2CCCC(=O)c3ccccc32)c(C)c1</smiles>

SCHeme 21: Synthetic route for Impurity T. 

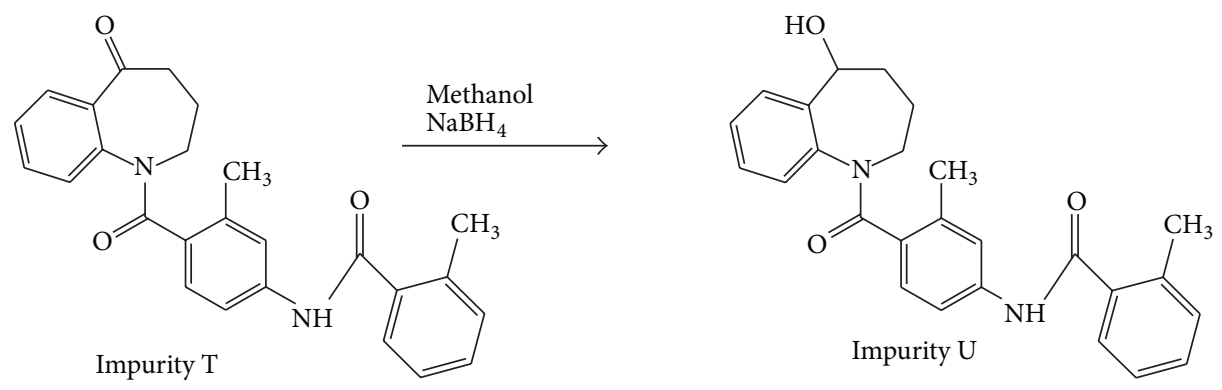

Scheme 22: Synthetic route for Impurity U.

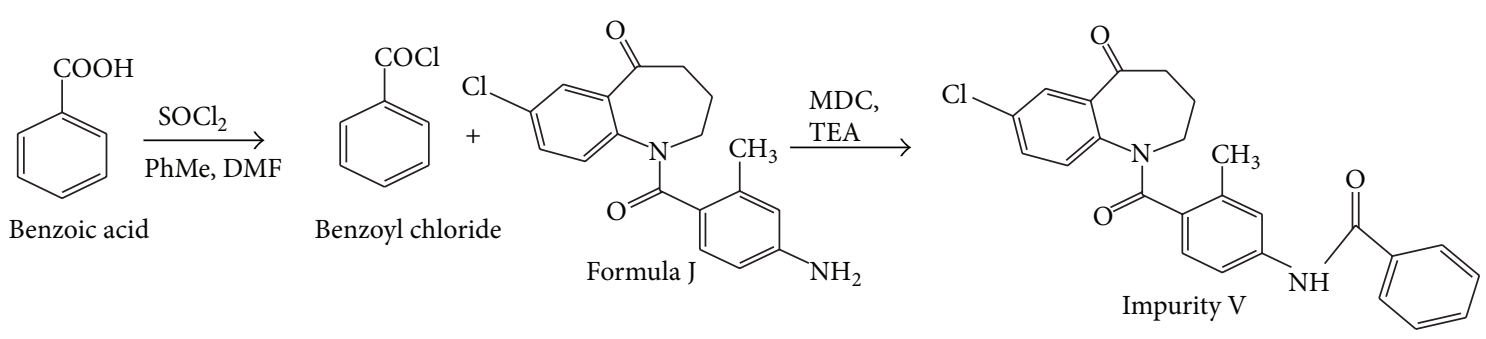

SCHEME 23: Synthetic route for Impurity V.

of TLV-2 $(8 \mathrm{~g}, 0.0243 \mathrm{~mol})$ in MDC $(80 \mathrm{~mL})$, triethyl amine $(10 \mathrm{~mL}, 0.0732 \mathrm{~mol})$ was added. Reaction mixture was stirred for 15 minutes. Isolated acid chloride of benzoic acid was added to the reaction mixture and stirred for 45 minutes. $\mathrm{RM}$ was washed with $\mathrm{DM}$ water $(60 \mathrm{~mL})$ and with dilute $\mathrm{HCl}$ (60 mL, 10\%). Organic layer was separated, dried over sodium sulfate, and distilled under vacuum to get product as yellow solid (Scheme 23).

$(7.5 \mathrm{~g}, \%$ Yield $=70 \%)$ HPLC purity $=77.7 \%$ which is further purified by flash column chromatography to obtain compound of purity $99 \%$. MS $m / z=433.1(\mathrm{M}+\mathrm{H}){ }^{1} \mathrm{H}$ NMR (300 MHz, DMSO-d $\left.\mathrm{d}_{6}, \delta / \mathrm{ppm}\right) 1.45-1.68(2 \mathrm{H}, m), 1.84-1.90$ $(1 \mathrm{H}, m), 2.10-2.11(1 \mathrm{H}, m), 2.35(3 \mathrm{H}, s), 2.60-2.70(1 \mathrm{H}, m)$, 4.63-4.67 $(1 \mathrm{H}, m), 6.60-6.79(2 \mathrm{H}, m), 7.02-7.06(1 \mathrm{H}, d d, J=$ $7.0 \mathrm{~Hz}, J=2.8 \mathrm{~Hz}), 7.24-7.44(2 \mathrm{H}, m), 7.48-7.61(3 \mathrm{H}, m), 7.90$ $(2 \mathrm{H}, d), 10.18(1 \mathrm{H}, s)$.

2.2.23. Preparation of Tolvaptan Impurity $W$. To a solution of $\mathrm{V}(3.5 \mathrm{~g}, 0.00810 \mathrm{~mol})$ in methanol $(40 \mathrm{~mL})$ at $0^{\circ} \mathrm{C}$ sodium borohydride $(0.5 \mathrm{~g}, 0.0121 \mathrm{~mol})$ was added portionwise. Reaction mixture was stirred at the same temperature for $0.5 \mathrm{~h}$. Solvent of the reaction mixture was distilled under vacuum. MDC was added to the residue $(40 \mathrm{~mL})$ and washed with water $(40 \mathrm{~mL})$ and with dil. $\mathrm{HCl}(40 \mathrm{~mL})$. Organic layer was separated, dried over sodium sulfate, and distilled under vacuum to get product as light yellow solid (Scheme 24).

$(2.5 \mathrm{~g}, \%$ Yield $=71 \%)$. HPLC purity $=77.27 \%$ which is further purified by flash column chromatography. MS $m / z=$ $435.1(\mathrm{M}+\mathrm{H}) .{ }^{1} \mathrm{H}$ NMR $\left(300 \mathrm{MHz}, \mathrm{DMSO}_{-} \mathrm{d}_{6}, \delta / \mathrm{ppm}\right) 1.44-$ $1.77(2 \mathrm{H}, m), 1.94-1.99(1 \mathrm{H}, m), 2.11-2.14(1 \mathrm{H}, m), 2.35(3 \mathrm{H}, s)$, 2.65-2.73 (1H, m), 4.63-4.67 (1H, m), 4.80-4.92 (1H, $m), 5.70$ $(1 \mathrm{H}, d, J=7.0 \mathrm{~Hz}), 6.60-6.79(2 \mathrm{H}, m), 7.02-7.06(1 \mathrm{H}, d d, J=$ $7.1 \mathrm{~Hz}, J=2.7 \mathrm{~Hz}), 7.24-7.44(2 \mathrm{H}, m), 7.48-7.61(3 \mathrm{H}, m), 7.90$ $(2 \mathrm{H}, d, J=7.1 \mathrm{~Hz}), 10.18(1 \mathrm{H}, s)$.
2.2.24. Preparation of Tolvaptan Impurity X. 2-Methyl-4nitro benzoic acid $(20 \mathrm{~g}, 0.1101 \mathrm{~mol})$ is stirred with Toluene $(200 \mathrm{~mL})$ and thionyl chloride $(20 \mathrm{~g} 0.168)$ with stirring at room temperature for about one hour was added (Scheme 25). During which reaction mixture was heated to reflux for two hours. After confirming the absence starting material solvent was removed by atmospheric distillation. The obtained crude was diluted with dichloromethane, The reaction mass was slowly added to stirred mixture of 7-chloro-1,2,3,4-tetrahydrobenzo[b]azepin-5-one $(8.64 \mathrm{~g}$ $0.044 \mathrm{~mol})$ in dichloromethane and triethylamine $(55 \mathrm{~g}$, $0.5520 \mathrm{~mol}$ ). Reaction mixture was stirred at room temperature for 6 hours to complete reaction. The resulting reaction mixture was slowly added to a vessel containing $100 \mathrm{~mL}$ of $10 \%$ sodium chloride under stirring. The organic layer is separated and washed twice with $1 \mathrm{~N}$ $\mathrm{HCl}(100 \mathrm{~mL})$ and $5 \%$ sodium bicarbonate $(100 \mathrm{~mL})$ solution and dried over sodium sulphate, sodium sulfate was removed by filtration, and the filtrate was concentrated under reduced pressure to give 2-methyl-4-nitro-benzoic acid 7-chloro-1-(2-methyl-4-nitro-benzoyl)-2,3-dihydro- $1 \mathrm{H}$ benzo[b]azeoin-5-yl-ester (Yield 82\%) HPLC purity $=99.0 \%$, MS $m / z=522(\mathrm{M}+\mathrm{H}),{ }^{1} \mathrm{H}$ NMR $\left(300 \mathrm{MHz}, \mathrm{DMSO}_{-} \mathrm{d}_{6}\right.$, $\delta / \mathrm{ppm})$ 2.68-2.71 (1H, $m), 2.71(6 \mathrm{H}, s), 2.91-3.11(2 \mathrm{H}, m)$, $4.78-4.82(1 \mathrm{H}, m), 6.94(1 \mathrm{H}, d, J=7.2 \mathrm{~Hz}), 7.15-7.18(1 \mathrm{H}, d d, J$ $=7.3 \mathrm{~Hz}, J=2.6 \mathrm{~Hz}), 7.43-7.48(1 \mathrm{H}, m), 7.79(1 \mathrm{H}, m), 8.09(1 \mathrm{H}$, s), 8.23-8.27 (1H, $d d, J=7.3 \mathrm{~Hz}, J=2.6 \mathrm{~Hz}), 8.32(1 \mathrm{H}, d, J=$ $7.4 \mathrm{~Hz}), 8.41(1 \mathrm{H}, d, J=7.2 \mathrm{~Hz})$.

2.2.25. Preparation of Tolvaptan Impurity $Y$. To a stirred mixture of methanol $(240 \mathrm{~mL})$ and concentrated $\mathrm{HCl}$ (84 mL), 2-methyl-4-nitro-benzoic acid 7-chloro-1-(2methyl-4-nitro-benzoyl)-2,3-dihydro-1H-benzo[b]azeoin-5yl-ester $(12 \mathrm{~g} 0.023 \mathrm{~mol})$ was added and $\mathrm{SnCl}_{2} \cdot 2 \mathrm{H}_{2} \mathrm{O}(42 \mathrm{~g}$ 
<smiles>Cc1cc(NC(=O)c2ccc([AlH2])cc2)ccc1C(=O)Nc1ccc(C(=O)N2CCCC(O)c3cc(Cl)ccc32)c(C)c1</smiles>

Scheme 24: Synthetic route for Impurity W.<smiles>Cc1cc([N+](=O)[O-])ccc1C(=O)OC1=CCCN(C(=O)c2ccc([N+](=O)[O-])cc2C)c2ccc(Cl)cc21</smiles>

SCHEME 25: Synthetic route for Impurity X.

$0.186 \mathrm{~mol})$ with stirring at room temperature was added (Scheme 26). The reaction mass was maintained at reflux temperature for 2 hours. After confirming the disappearance of starting material, the crude obtained was diluted with dichloromethane and added water. The biphase obtained adjusted the $\mathrm{pH}$ of reaction mass $12-14$ using $40 \% \mathrm{NaOH}$ solution. Layer was washed with water $(2 \times 100 \mathrm{~mL})$ and sodium bicarbonate $(2 \times 100 \mathrm{~mL})$ and dried over sodium sulfate, after filtering off sodium sulfate; the filtrate was concentrated under reduced pressure to give the crude product. The resultant crude was with ethyl acetate to give 4-amino-2-methyl-benzoic acid 1-(4-amino-2-methylbenzoyl)-7-chloro-2, 3-dihydro-1H-benzo[b]azepin-5-ylester. The crude product purified in column chromatography using 60-120 mesh silica gel and product was eluted in 30\% ethyl acetate in Hexane.

(Yield-56\%) (HPLC-92.0\%), MS m/z = 462 (M+H), ${ }^{1} \mathrm{H}$ NMR $\left(300 \mathrm{MHz}, \mathrm{DMSO}_{-} \mathrm{d}_{6}, \delta / \mathrm{ppm}\right) 2.25(3 \mathrm{H}, s), 2.45(3 \mathrm{H}$, s), 2.58-2.59 (1H,s), 2.72-2.79 (2H, s), $4.79(1 \mathrm{H}, m), 6.03-6.08$ $(4 \mathrm{H}, m), 6.29(1 \mathrm{H}, d, J=7.0 \mathrm{~Hz}), 6.47-6.54(2 \mathrm{H}, m), 6.70(1 \mathrm{H}$, $d, J=7.2 \mathrm{~Hz}), 6.77(1 \mathrm{H}, d, J=7.2 \mathrm{~Hz}), 7.08-7.12(1 \mathrm{H}, d d, J=$ $7.2 \mathrm{~Hz}, J=2.6 \mathrm{~Hz}), 7.29(1 \mathrm{H}, d, J=7.1 \mathrm{~Hz}), 7.95(1 \mathrm{H}, d, J=$ $7.1 \mathrm{~Hz})$.

2.2.26. Preparation of Tolvaptan Impurity Z. 4-Amino-2methyl-benzoic acid 1-(4-amino-2-methyl-benzoyl)-7-chloro-2,3-dihydro-1H-benzo[b]azepin-5-yl-ester (5 g $\quad 0.0108$ $\mathrm{mol})$ was dissolved in dichloromethane $(50 \mathrm{~mL})$ and triethylamine $(7.5 \mathrm{~mL} 0.054 \mathrm{~mol})$ and O-toluoyl chloride $(4.17 \mathrm{~g}$ $0.027 \mathrm{~mol}$ ) was added with stirring under ice cooling over a period of 30 minutes (Scheme 27). After confirming the disappearance of starting material, dichloromethane layer was washed with water $(2 \times 50 \mathrm{~mL})$ and $5 \%$ sodium bicarbonate $(2 \times 50 \mathrm{~mL})$ and dried over sodium sulfate; after filtering off sodium sulfate, the filtrate was concentrated under reduced pressure to give the crude product. The resultant crude was recrystallized in isopropyl ether to give 2-Methyl-4-(2-methyl-benzoylamino)-benzoic acid 7chloro-1-[2-methyl-4-(2-methyl-benzoylamino)benzoyl]-2, 3-dihydro-1H-benzo[b]azepin-5-yl-ester.

(Yield-65\%) (HPLC-98.0\%) MS $m / z=698(\mathrm{M}+\mathrm{H}){ }^{1} \mathrm{H}$ NMR $\left(300 \mathrm{MHz}, \mathrm{DMSO}-\mathrm{d}_{6}, \delta / \mathrm{ppm}\right) 2.35(3 \mathrm{H}, s), 2.40(6 \mathrm{H}$, s), $2.59(3 \mathrm{H}, s), 2.59-2.67(1 \mathrm{H}, m), 2.87-3.01(2 \mathrm{H}, m), 4.82-$ $4.85(1 \mathrm{H}, m), 6.26(1 \mathrm{H}, m), 6.83(1 \mathrm{H}, d), 7.12-7.18(1 \mathrm{H}, m), 7.27-$ $7.51(12 \mathrm{H}, m), 7.81-7.84(2 \mathrm{H}, m), 8.25(1 \mathrm{H}, d, J=7.1 \mathrm{~Hz}), 10.26$ $(1 \mathrm{H}, s), 10.66(1 \mathrm{H}, s)$.

\section{Results and Discussion}

This impurity (Impurity A) could be formed when unreacted 7-Chloro-1,2,3,4-tetrahydro-benzo[b]azepin-5-one from the first stage reacts with o-toluoyl chloride which is added in the third stage. Impurity B is possible when Impurity A is carried over to the fourth stage and gets reduced. Impurity $\mathrm{C}$ is possible when unreacted 2-methyl 4-nitro benzoic acid is reduced and then condensed with o-toluoyl chloride in the third stage. Complete consumption of 2-methyl 4-nitro benzoyl chloride would limit the formation of this impurity. Impurity D is possible if unreacted TLV-2 is carried forward to the fourth step. Impurity $\mathrm{E}$ is possible if unreacted otoluoyl chloride reacts with the Tolvaptan (TLV-4). Impurity $\mathrm{F}$ is possible when 4-nitro benzoic acid is present as an impurity in starting material 2-methyl 4-nitro benzoic acid. Impurity $\mathrm{G}$ is possible if Impurity F is carried forward to the second stage. Both Impurities $F$ and $G$ could be avoided by using 2-methyl 4-nitro benzoic acid which is free of 4-nitro 
<smiles>Cc1cc([N+](=O)[O-])ccc1C(=O)OC1=CCCN(C(=O)c2ccc([N+](=O)[O-])cc2C)c2ccc(Cl)cc21</smiles>

Impurity X

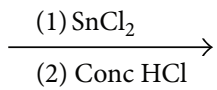<smiles>Cc1cc(N)ccc1C(=O)OC1=CCCN(C(=O)c2ccc(N)cc2C)c2ccc(Cl)cc21</smiles>

Impurity Y

SCHeme 26: Synthetic route for Impurity Y.<smiles>Cc1cc(N)ccc1C(=O)OC1=CCCN(C(=O)c2ccc(N)cc2C)c2ccc(Cl)cc21</smiles>

Impurity Y<smiles>Cc1ccccc1C(=O)Cl</smiles>

(2) TEA

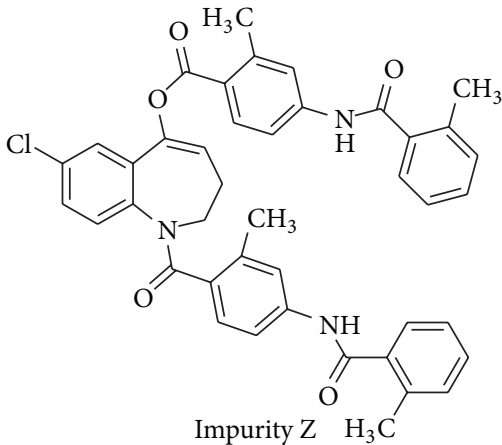

SCHeme 27: Synthetic route for Impurity Z.

benzoic acid impurity. Impurity $\mathrm{H}$ is possible when impurity $\mathrm{G}$ is carried forward to the next step. Impurity I is possible when impurity $\mathrm{H}$ is carried forward to the next step (Stage 4). Impurity $\mathrm{J}$ is possible when 4-methyl benzoic acid is present as an impurity in 2-methyl 4-nitro benzoic acid. Impurity $\mathrm{K}$ is possible when impurity J is carried forward to the next step (Stage 4). Impurity L is possible when 3-methyl benzoic acid is present as an impurity in 2-methyl 4-nitro benzoic acid. Impurity $\mathrm{M}$ is possible when Impurity $\mathrm{L}$ is carried forward to next step (Stage 4). Impurity $\mathrm{N}$ is possible when $3-4$, dimethyl benzoic acid is present as an impurity in 2-methyl 4 -nitro benzoic acid. Impurity $\mathrm{O}$ is possible when impurity $\mathrm{N}$ is carried forward to the next step (Stage 4). Impurity $\mathrm{P}$ is possible when 2,3-dimethyl benzoic acid is present as an impurity in 2-methyl 4-nitro benzoic acid. Impurity Q is possible when Impurity $\mathrm{P}$ is carried forward to the next step (Stage 4). Impurity $\mathrm{S}$ is possible when Impurity $\mathrm{R}$ is carried forward to the second step.

Impurity $\mathrm{T}$ is possible when Impurity $S$ is carried forward to the third step. Impurity $\mathrm{U}$ is possible when Impurity $\mathrm{T}$ is carried forward to the fouth step. Impurity $\mathrm{V}$ is possible when benzoic acid is present as an impurity in o-toluoyl chloride and could be formed in the third stage. Impurity $\mathrm{W}$ is possible when Impurity $\mathrm{V}$ is carried forward to the fourth step. This impurity is observed at $0.97 \mathrm{RRT}$ in the LCMS of TLV-4. Impurity X is formed when 7-chloro-1,2,3,4tetrahydrobenzo[b]azepin-5-one is reacted with 2-methyl 40 nitro benzoyl chloride in presence of a base such as triethyl amine. In order to avoid formation of this impurity the reaction is carried out in absence of base. This impurity is observed at 1.36 RRT in the chromatogram of the first stage. Impurity $\mathrm{Y}$ is possible when Impurity $\mathrm{X}$ is carried forward to the second step. Impurity $\mathrm{Z}$ is possible when Impurity $\mathrm{Y}$ is carried forward to the fourth step. This impurity is observed at $1.44 \mathrm{RRT}$ in the chromatogram of the third stage.

\section{Conclusion}

In conclusion different observed as well as potential impurities formed during the process for Tolvaptan have been described with their synthetic procedure and characterization data. International Conference on Harmonization (ICH) has formulated guidelines regarding the control of impurities and hence impurity profiling is a critical issue to the pharmaceutical industry. Keeping in view the regulatory importance of Tolvaptan, synthesis and characterization of these impurities could be highly beneficial. This paper outlines the description of different impurities related to Tolvaptan and their methods of synthesis.

\section{Conflict of Interests}

The authors declare that there is no conflict of interests regarding the publication of this paper.

\section{Acknowledgments}

The authors' group thanks the Department of Scientific and Industrial Research, India, Dr. Hari Babu (CEO of Mylan Laboratories Ltd., India), Mr. Sanjeev Sethi (Head of Mylan 
Global R \& D), Dr. Ramesh Dandala (Head of MLL R \& D), and Dr. Suryanarayana Mulukutla (Head of Analytical Dept., MLL R \& D) as well as Analytical Development Team of Mylan Laboratories Ltd. for their encouragement and support. They would also like to thank Dr. Narahari Ambati (Head of IPR MLL R \& D) and his intellectual property team for their support.

\section{References}

[1] L. L. Lohr, T. R. Sharp, K. M. Alsante, and T. D. Hatajik, "Isolation and identification of process related impurities and degradation products from pharmaceutical drug candidates. Part 1," American Pharmaceutical Review, vol. 4, no. 1, pp. 70-78, 2001.

[2] S. Görög, "Chemical and analytical characterization of related organic impurities in drugs," Analytical and Bioanalytical Chemistry, vol. 377, no. 5, pp. 852-862, 2003.

[3] N. R. Rao, S. S. Mani Kiran, and N. L. Prasanthi, "Pharmaceutical impurities: an overview," Indian Journal of Pharmaceutical Education and Research, vol. 44, no. 3, pp. 302-306, 2010.

[4] S. Ahuja, Impurities Evaluation of Pharmaceuticals, Mercel Dekker, New York, NY, USA, 1998.

[5] R. W. Schrier, P. Gross, M. Gheorghiade et al., "Tolvaptan, a selective oral vasopressin V2-receptor antagonist, for hyponatremia," The New England Journal of Medicine, vol. 355, no. 20, pp. 2099-2112, 2006.

[6] J. K. Ghali, B. Hamad, U. Yasothan, and P. Kirkpatrick, "Tolvaptan," Nature Reviews Drug Discovery, vol. 8, no. 8, pp. 611-612, 2009.

[7] G. R. Belum, V. R. Belum, S. K. Chaitanya Arudra, and B. S. N. Reddy, "The Jarisch-Herxheimer reaction: revisited," Travel Medicine and Infectious Disease, vol. 11, no. 4, pp. 231-237, 2013.

[8] H. D. Zmily, S. Daifallah, and J. K. Ghali, "Tolvaptan, hyponatremia, and heart failure," International Journal of Nephrology and Renovascular Disease, vol. 4, pp. 57-71, 2011.

[9] M. N. Ferguson, "Novel agents for the treatment of hyponatremia: a review of conivaptan and tolvaptan," Cardiology in Review, vol. 18, no. 6, pp. 313-321, 2010.

[10] H. Ogawa, H. Miyamoto, K. Kondo et al., US5258510, 1993.

[11] K. Kondo, H. Ogawa, H. Yamashita et al., "7-Chloro-5-hydroxy1-[2-methyl-4-(2-methylbenzoylamino)benzoyl]-2,3,4,5- tetrahydro-1H-1-benzazepine (OPC-41061): a potent, orally active nonpeptide arginine vasopressin V2 receptor antagonist," Bioorganic and Medicinal Chemistry, vol. 7, no. 8, pp. 1743-1754, 1999. 

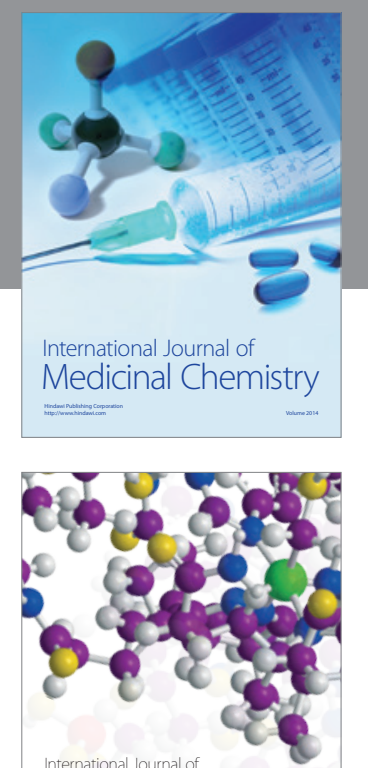

\section{Carbohydrate} Chemistry

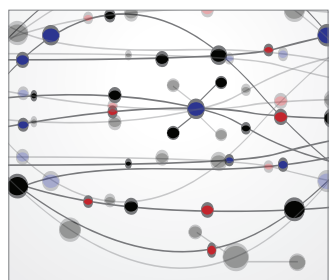

The Scientific World Journal
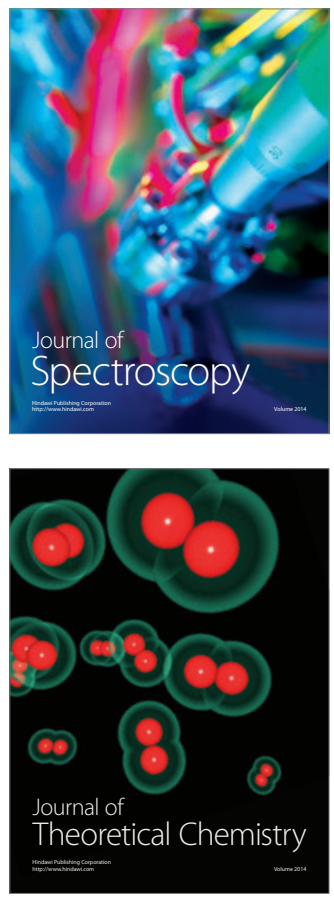
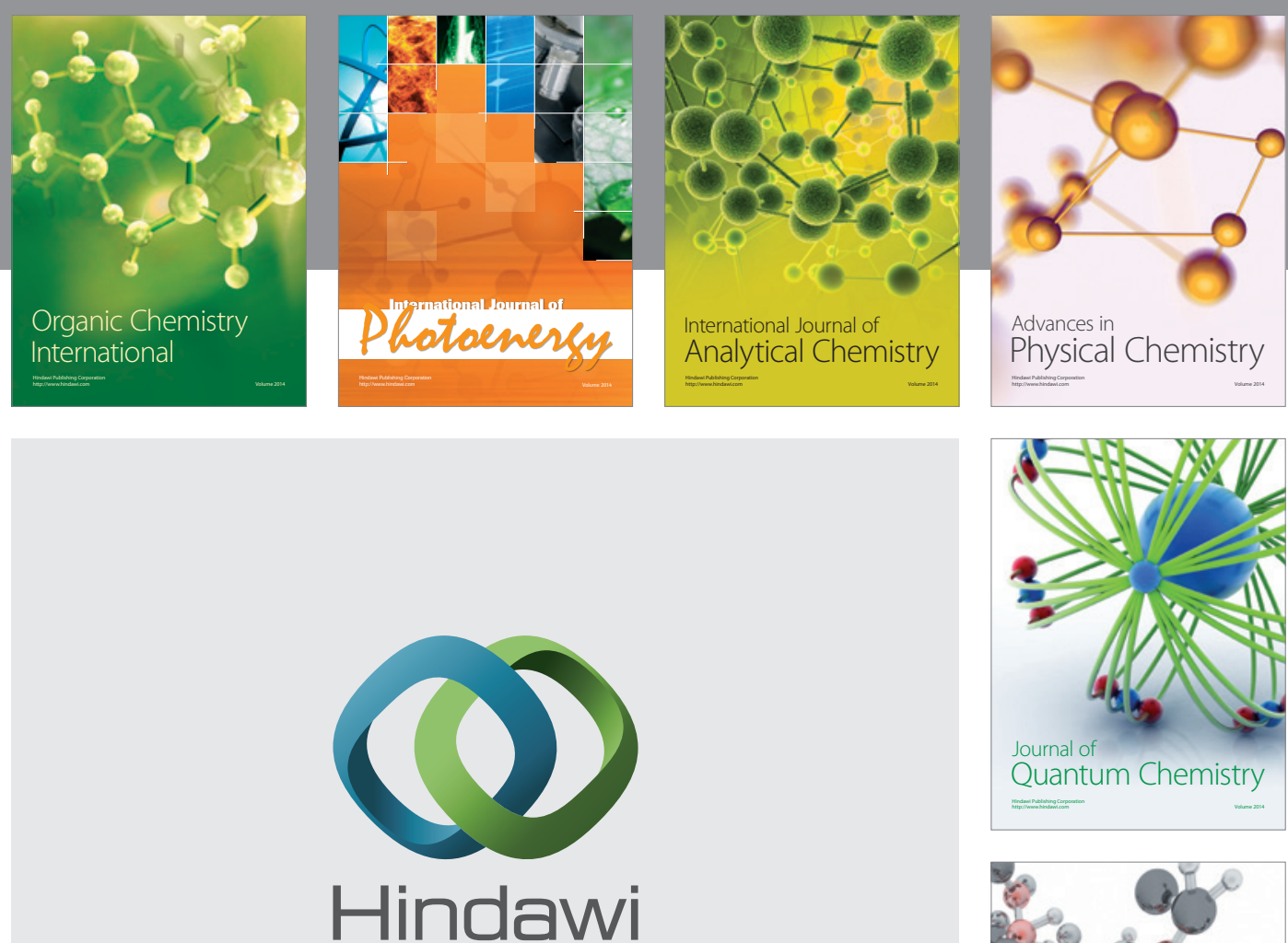

Submit your manuscripts at

http://www.hindawi.com

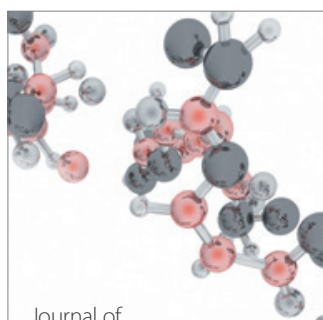

Analytical Methods

in Chemistry

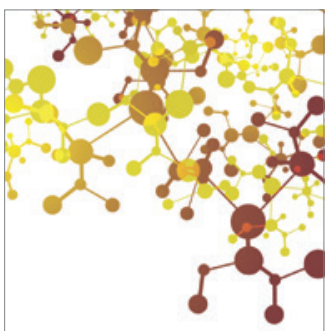

Journal of

Applied Chemistry

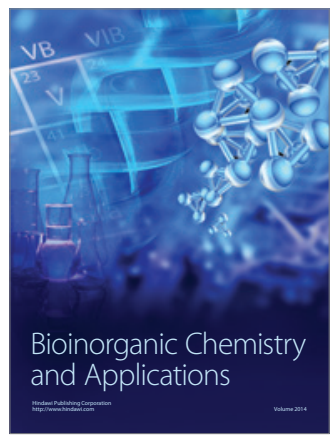

Inorganic Chemistry
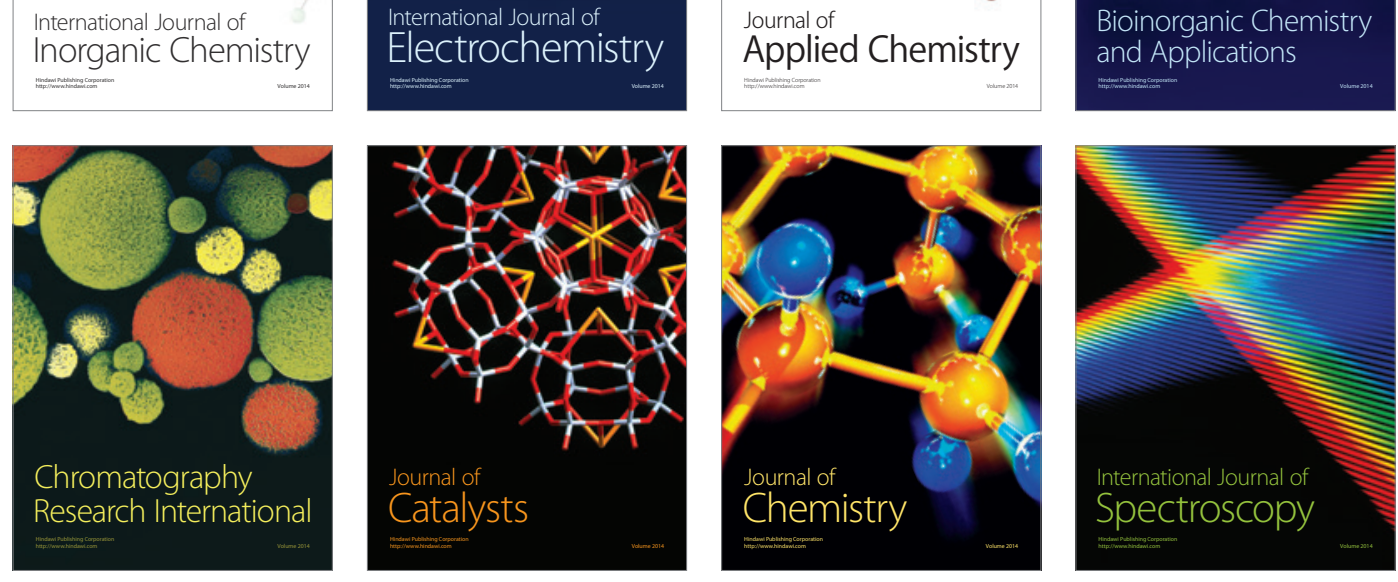